\title{
The effect of endotoxin-contaminated medium on in vitro fertilization and development of bovine oocytes matured in vitro
}

\author{
V Madison ${ }^{1}, T_{\text {Greve }}{ }^{*}$, B Avery 1, T Wamberg 2 \\ with the technical assistance of $V$ Mortensen ${ }^{1}, M$ Balle ${ }^{2}, \mathrm{R}$ Høier ${ }^{1}$ \\ 1 Royal Veterinary and Agricultural University, Department of Reproduction; \\ 2 Royal Veterinary and Agricultural University, Department of Pharmacology, \\ 13 Bülowsvej, DK-1870 Frederiksberg C, Denmark
}

(4th Franco-Czechoslovak Meeting, Prague 1990)

\begin{abstract}
Summary - The purpose of this study was to determine whether the presence of bacterial endotoxin in the bovine serum albumin (BSA) used to supplement media utilized for sperm preparation and co-culture of bovine sperm and oocytes affects in vitro penetration and embryonic development of oocytes matured in vitro. The chromogenic limulus amoebocyte lysate (LAL) test was used for quantification of the content of endotoxin. The proportion of penetrated ova was significantly greater $(P>0.0005)$ for the endotoxin-contaminated group $(89 \%)$ versus the non-contaminated group $(61 \%)$, but this was probably not due to endotoxin contamination. The presence of endotoxin resulted in a high rate of polyspermy (27\% versus $4 \%$, respectively; $P>0.0005)$, while the occurrence of parthenogenetic activation was the same for each group (8\%). The proportion of total embryos put into culture that developed to the blastocyst stage by day 8 was similar (30\% and $26 \%$ ) for the contaminated and non-contaminated group, respectively. Fifty-three and $69 \%$, respectively, hatched on day 10 . These results suggest that endotoxin induces polyspermy, but has no adverse effect on embryonic development.
\end{abstract}

in vitro / cattle / embryo / endotoxin / LAL-test

Résumé - Effet de la contamination du milleu par des endotoxines sur la fécondation in vitro et le développement d'ovocytes bovins maturés in vitro. Le but de ce travail est de déterminer si des endotoxines bactériennes, présentes dans le sérum albumine bovine (BSA), additionnée aux milieux utilisés pour la préparation de sperme bovin et sa coculture avec des ovocytes, affecte la pénétration et le développenent embryonnaire in vitro. Le test chromogénique d'amabocytes de Limule (LAL) a été utilisé pour quantifier les endotoxines. La proportion d'coufs pénétrés du groupe contaminé fut significativement supérieure $(89 \% ; \mathrm{P}<0,000$ 5) à celle du groupe non contaminé par des endotoxines (61\%). En fait, la présence d'endotoxines induit un fort pourcentage de polyspermie (27\% contre $4 \%$ pour les témoins), alors que la fréquence d'activation parthogénétique est la même dans chaque groupe (8\%). La proportion de zygotes qui deviennent des blastocystes in vitro au jour 8 est semblable pour les groupes contaminé et non contamine (30\% et $26 \%$ respectivement). Parmi ces blastocystes, $53 \%$ et $69 \%$ respectivement éclosent le jour 10 . Ces résultats suggèrent que les endotoxines induisent la polyspermie, mais qu'elles n'ont pas d'effet sur le développement embryonnaire.

culture in vitro / embryon bovin / endotoxine / test LAL

\footnotetext{
* Correspondence and reprints
} 


\section{INTRODUCTION}

The bacterial toxin known as endotoxin, lipopolysaccharide or pyrogen is a biologically active lipid that makes up the outer monolayer of the outer membrane of Gram-negative bacteria (Raetz et al, 1988). Endotoxic fragments are released from bacterial cells after their death, either by natural autolysis or artificial disruption. Treatment of media and water by conventional methods of heat or chemical sterilization or filtration neither alters the properties of endotoxin nor removes endotoxic fragments.

The actions of endotoxin on the mammalian organism are known and relatively well characterized (Nowotny, 1971; Culbertson $\mathrm{Jr}$ and Osburn, 1980). To a lesser degree, the harmful effects of endotoxin on somatic cells in culture have been investigated (Freer and Arbuthnott, 1976; Silver, 1981). Recently, the exposure of human gametes to media contaminated by endotoxin resulted in a reduction in the number of successful pregnancies following fertilization in vitro, indicating that gametes are also negatively affected by endotoxin (Snyman and van der Merwe, 1986; Fishel et al, 1988).

In our laboratory, procedures used for bovine oocyte maturation and fertilization, and embryo culture in vitro are being compared in an attempt to optimize results. The purpose of this study was to determine whether the presence of endotoxin in the bovine serum albumin (BSA) used to supplement media utilized for sperm preparation and for sperm oocyte co-culture alters the proportion of oocytes with normal sperm penetration and subsequent embryo development, compared with media supplemented with BSA known to be practically free of endotoxin.

\section{MATERIALS AND METHODS}

\section{Conditions for maturation in vitro}

Ovaries and oviducts were collected from cows or heifers at the abattoir within $30 \mathrm{~min}$ of slaughter. The ovaries were transported at $35^{\circ} \mathrm{C}$ in phosphate-buffered saline (PBS) containing 25 $\mathrm{mg} / \mathrm{l}$ kanamycin, whereas the oviducts were maintained at ambient temperature (approximately $20^{\circ} \mathrm{C}$ ). The organs were delivered to the laboratory within 1 to $3 \mathrm{~h}$ after their collection.

Immature oocytes were aspirated from antral follicles approximately 2 to $6 \mathrm{~mm}$ in diameter. Following aspiration, selected oocytes surrounded by a compact mass of cumulus and corona cells, or only a complete layer of corona cells, were washed 3 times in oocyte washing medium. This medium consisted of Hepes-buffered TCM 199 (Seromed) supplemented with 20\% heat-inactivated estrous cow serum (ECS, collected on the day of estrus), $0.4 \mathrm{mM} \mathrm{L}$ glutamine, $0.2 \mathrm{mM}$ sodium pyruvate and $50 \mu \mathrm{g} /$ $\mathrm{ml}$ gentamycin. Subsequently, the oocytes were washed once in oocyte maturation medium, which was based on sodium bicarbonatebuffered TCM 199 (Seromed) and supplemented as described above. The procedures of follicle aspiration and oocyte washing were performed at room temperatures of $37^{\circ} \mathrm{C}$ and $34^{\circ}-$ $35^{\circ} \mathrm{C}$, respectively.

Ten selected and washed oocytes were placed into each $100-\mu$ l droplet of oocyte maturation medium with an overlay of extracted and equilibrated paraffin oil. incubation was for about $25 \mathrm{~h}$ at $39^{\circ} \mathrm{C}$ in an atmosphere of high humidity and $5 \% \mathrm{CO}_{2}$ in air. Subsequently, a portion of ova was fixed and assessed for completion of meiotic maturation (Süss et al, 1988).

\section{Conditions for fertilization in vitro}

Following maturation the ova were randomly divided into 2 groups. Those in Group I were washed 3 times in modified Hepes buffered Tyrode's medium (Hepes-TALP), then once in IVFTALP (Viuff et al, 1990). Each of these media 
was supplemented with essentially fatty acidfree BSA (BSA-FAF, Sigma) that had been assessed for endotoxin and shown to be contaminated (table I). These ova were subsequently placed into droplets (final vol of $100 \mu$ l) of IVFTALP overlaid with paraffin oil. The ova of group II were treated in a similar manner, except the media were supplemented with Fraction-V BSA (BSA-V, Sigma) that was guaranteed by the manufacturer to be cell-culture tested and to contain less than $0.1 \mathrm{ng}$ endotoxin (detectable) per mg. For each group, the IVF-TALP contained $10 \mu \mathrm{g} / \mathrm{ml}$ heparin, $20 \mu \mathrm{M}$ D-penicillamine, $10 \mu \mathrm{M}$ hypotaurine and $1 \mu \mathrm{M}$ epinephrine.

Frozen semen of 1 selected bull was used for fertilization. Upon thawing, the semen was divided between groups I and II and the spermatozoa were washed once in Sperm-TALP (Viuff et al, 1990) supplemented with either BSA-FAF or $B S A-V$, respectively, by centrifugation at $200 \mathrm{~g}$ for $10 \mathrm{~min}$. This was followed by swim-up, in the appropriate Sperm-TALP medium, in a water bath set into the incubator $\left(39^{\circ} \mathrm{C}\right)$. The swim-up procedure was perfo rmed as described by Parrish et al (1986). The swim-up supernatant of each group was centrifuged, then the concentration of spermatozoa was adjusted to $25 \times 10^{6}$ sperm/ml. Four $\mu l$ of the final sperm suspension from each group were added to each droplet of the respective IVF-TALP medium containing ova. The expanded masses of cumulus cells were not removed from the ova before exposure to spermatozoa. The conditions for incubation were the same as those used for oocyte maturation. After 21 to $22 \mathrm{~h}$ of incubation a portion of ova from each group was fixed and stained, then examined for penetration (Xu and Greve, 1988).

\section{Conditions for zygote and embryo culture in vitro}

Each group of ova was again kept separate during the subsequent procedures. About $25 \mathrm{~h}$ after initiation of in vitro insemination, all ova were pipetted to remove cumulus cells and adhering spermatozoa. During this procedure the ova were washed 3 times in Hepes-TALP-BSA (supplemented with $3 \mathrm{mg} / \mathrm{ml}$ BSA-V), then once in embryo culture medium. This medium was composed of $\mathrm{B}_{2}$ medium (Ménézo, 1976) (APISystem, purchased from BICEF, France) supplemented with $10 \%$ ECS and $2.5 \mu \mathrm{g} / \mathrm{ml}$ fungizone. Twenty to 25 ova were placed into each droplet (final vol of $50 \mu \mathrm{l}$ ) of embryo culture medium. Bovine oviduct epithelial cells (BOEC) had been transferred into each droplet about $3 \mathrm{~h}$ prior to addition of the ova. The droplets were overlaid with paraffin oil and the conditions for incubation were similar to those used for oocyte maturation.

During each experiment the occurrence of parthenogenetic activation was assessed by ex-

Table I. Level of endotoxin in water, media and protein sources used for maturation and fertilization of oocytes, and embryo culture in vitro.

\begin{tabular}{lcc}
\hline Source & EU/m/-1 & $n g / \mathrm{ml}$ \\
\hline & & \\
Milli-Q water & 0.04 & 0.00 \\
IVF-TL (stock) & 1.12 & 0.09 \\
IVF-TALP (with BSA-V) & 3.51 & 0.29 \\
IVF-TALP (with BSA-FAF) & $>66.62$ & $>5.55$ \\
ECS & 2.97 & 0.25 \\
Oocyte maturation medium & 3.28 & 0.27 \\
Embryo culture medium & 10.66 & 0.89 \\
BSA-FAF (undiluted) & $27.18 \mathrm{EU} / \mathrm{mg}$ & $2.26 \mathrm{ng} / \mathrm{mg}^{2}$ \\
BSA-V (undiluted) & & $<0.10 \mathrm{ng} / \mathrm{mg}^{2}$ \\
\hline
\end{tabular}

1 Endotoxin units per $\mathrm{ml} ;{ }^{2}$ this value was provided by Sigma. 
posing 2 portions of ova to washing procedures and conditions for fertilization in vitro for group I and II, except spermatozoa were not added to the droplets. Subsequently, these ova were cocultured in embryo culture medium with BOEC.

Three days after initiation of insemination, 50 $\mu l$ of embryo culture medium was added to each droplet. Incubation was continued for another 5 d (=d 8 post-insemination), after which the proportion of normal blastocysts was determined. After a further $2 d$, the cultures were assessed for the number of blastocysts that had hatched completely from the zona pellucida. The occurence of cleavage was used as the criterion for parthenogenetic activation.

The BOEC were prepared in the following manner. Upon arrival in the laboratory, the oviducts were dissected free of surrounding tissue and rinsed with Hepes-TALP-ECS (supplemented with $2.5 \mu \mathrm{g} / \mathrm{ml}$ fungizone and $10 \%$ ECS, rather than BSA). Using forceps, cells were squeezed from the lumen of a pair of oviducts into Hepes-TALP-ECS. After sedimentation of the celis and removal of the supernatant, the cell pellet was resuspended and then passed in and out through a 25 gauge needle to break the sheets of tissue into smaller fragments. These cells were washed twice in Hepes-TALP-ECS by centrifugation. The pellet was resuspended at a concentration of 1:50 (v/v) in a medium consisting of sodium bicarbonate-buffered TCM 199, 10\% ECS, $0.7 \mathrm{mM}$ L-glutamine, $0.2 \mathrm{mM}$ sodium pyruvate, $50 \mu \mathrm{g} / \mathrm{ml}$ gentamycin and 2.5 $\mu \mathrm{g} / \mathrm{ml}$ fungizone. Five $\mathrm{ml}$ of this suspension were cultured per $25 \mathrm{~cm}^{3}$ culture flask. After about 30 h of culture, the BOEC were washed 3 times by sedimentation in Hepes-TALP-BSA (supplemented with $3 \mathrm{mg} / \mathrm{ml}$ BSA-V), then once in embryo culture medium before culture in this medium at a concentration of $1: 50(\mathrm{v} / \mathrm{v})$. These cultures were performed in 4-well plates with 1 $\mathrm{ml}$ cell suspension per well. After $18 \mathrm{~h}$ of culture, the BOEC were again washed 3 times in Hepes-TALP-BSA and once in embryo culture medium before placement of $2 \mu \mathrm{l}$ of pellet into each droplet of embryo culture medium.

Data were analyzed by $\chi^{2}$ using Yates adjustment for continuity (Box et al, 1978).

\section{Preparation of pyrogen-free material}

The chemicals and biological buffers used to prepare the TALP media, as well as the L- glutamine, sodium pyruvate, gentamycin and heparin, were purchased as either cell culture tested or hybridoma tested and, if available, also endotoxin tested. The media were prepared with water puritied by reverse osmosis-ion exchange (Milli-Q filtration system, Millipore). Purchased media were guaranteed as cell-culture tested and low endotoxin. Glassware was only used to maintain the ovaries prior to follicle aspiration and for preparation of the stock media used to prepare each TALP medium. This glassware was rendered pyrogen-free by baking for at least $4 \mathrm{~h}$ at $200^{\circ} \mathrm{C}$. All disposable material was pyrogen-free.

\section{Measurement of endotoxin}

Endotoxin in the media and supplements was quantitated by the LAL test (Coatest, KabiVitrum, Copenhagen, Denmark). The range of sensitivity of this test was 0.01 to $1.0 \mathrm{EU} / \mathrm{ml}$. Samples of water, stock media, complete media, ECS and BSA-FAF were taken to the Pharmacy of the Royal Veterinary and Agricultural University for analysis. Samples were diluted with sterile pyrogen-free water to provide an absorbancy $>0.02$ and $<1.25$. The samples containing serum or albumin were diluted 1:2 with water and boiled for $20 \mathrm{~min}$ to release the endotoxin from the protein.

Values for the level of contamination by endotoxin were derived as endotoxin units per $\mathrm{ml}$ $(E U / m l)$. The conversion factor for the reference endotoxin used for the test was stated by the manufacturer to be $12.0 \mathrm{EU}=1.0 \mathrm{ng} / \mathrm{ml}$ (table I) .

\section{RESULTS}

During performance of 4 replicates, a total of 895 oocytes was placed into maturation culture. The proportion of oocytes that completed meiotic maturation (anaphase I to metaphase II) was $80 \%$.

The levels of endotoxin in the media and supplements are shown in table 1 . The results for sperm penetration and embryo development for ova exposed to endotoxin 
(media supplemented with BSA-FAF), and for ova not exposed to endotoxin (media supplemented with BSA-V) are shown in table II.

The rate of penetration for ova exposed to endotoxin was significantly greater $(P<$ 0.0005 ) than for ova not exposed to endotoxin $(89 \%$ and $61 \%$, respectively). Howev$\mathrm{er}$, the proportion of ova with normal penetration was similar for each group due to the very high rate of polyspermy for ova exposed to endotoxin (27\%; $P<0.0005)$.

Exposure to endotoxin during culture without sperm did not induce parthenogenesis. The ova which were activated formed 2-, 3-, or 4-cells-usually symmetricalwithin $2 \mathrm{~d}$ after placement into droplets containing BOEC.

The proportion of unselected ova put into culture with BOEC that developed to the blastocyst stage (expanding, expand$e d$, hatching or hatched) by $\mathbf{d} 8$ after initiation of insemination was similar. Blastocysts that were small or degenerating were not included in the analysis. Of the normal blastocysts in the endotoxin-contaminated and non-contaminated groups, 53\% and
$69 \%$, respectively, had hatched completely from their zona pellucidae by $\mathrm{d} 10$. This difference was not statistically significant.

\section{DISCUSSION}

It was not possible to purchase an essentially fatty acid-free BSA that was guaranteed to be very low in endotoxin. Therefore we used two types of BSA to determine the effect of the presence of endotoxin in BSA used to supplement media utilized for sperm preparation and for sperm ova coculture.

We suspect the increased rate of penetration for the ova exposed to endotoxin was due to the fact that the BSA used in this group was essentially fatty acid-free, and not because of the endotoxic properties of this BSA. Serum albumin that has been rendered fatty acid-free is much more effective in inducing the acrosome reaction (Lui et al, 1977) and is generally in the form of albumin supplement used by groups performing in vitro fertilization in cattle.

Table II. Effect of type of BSA (BSA-FAF = with endotoxin, BSA-V = without endotoxin) on sperm penetration, parthenogenetic activation and embryo development.

\begin{tabular}{|c|c|c|c|c|c|c|}
\hline \multirow[t]{2}{*}{ Treatment } & \multicolumn{6}{|c|}{$\%$ of total examined (total in parentheses) } \\
\hline & Penetrated & Polyspermic & Activatec & $\begin{array}{l}\text { D } 8 \\
\text { blastocysts }\end{array}$ & $\begin{array}{l}\text { D } 10 \text { hatched } \\
\text { blastocysts }\end{array}$ & $\begin{array}{l}D \text { 10 hatched blastocysts } \\
\text { to d } 8 \text { blastocysts }\end{array}$ \\
\hline $\begin{array}{l}\text { BSA-FAF } \\
\text { BSA-V }\end{array}$ & $\begin{array}{l}89(83)^{a} \\
61(102)^{b}\end{array}$ & $\begin{array}{l}27(83)^{a} \\
4(102)^{b}\end{array}$ & $\begin{array}{l}8(36) \\
8(37)\end{array}$ & $\begin{array}{l}30(198) \\
26(178)\end{array}$ & $\begin{array}{l}17(132)^{3} \\
17(118)^{3}\end{array}$ & $\begin{array}{l}53(43)^{3} \\
69(29)^{3}\end{array}$ \\
\hline
\end{tabular}

\footnotetext{
1 Parthenogenetic activation: these ova were cultured $26 \mathrm{~h}$ without sperm, then co-cultured $10 \mathrm{~d}$ with bovine oviductal cells; ${ }^{2}$ Calculated from the total number of unselected zygotes-ova put into culture; ${ }^{3}$ These totals do not include the results of 1 experiment in which hatching was assessed on $\mathrm{d} 9$, rather than $\mathrm{d} 10$; a, $\mathrm{b} P<0.0005$ for (a) compared to (b) within columns.
} 
First and Parrish (1987) suggested that polyspermy may be the result of too many capacitated sperm and/or an over extended period of gamete co-culture. Our results demonstrate that exposure to endotoxin was associated with an abnormally high rate of polyspermy. We cannot rule out the possibility that BSA-FAF, rather than endotoxin, induced the high frequency of polyspermy. However, since other research groups which use BSA-FAF do not report such proportions of polyspermic ova, we suspect polyspermy was the result of alterations in the zona pellucida or oolemma caused by exposure to endotoxin. Hyttel et al (1989) indicated that polyspermic penetration of in vivo matured oocytes following fertilization in vitro is due to the in vitro environment. In that case, the lack of dispersal of cortical granule content into the perivitelline space was the cause of polyspermy. It is likely that endotoxin also interferes with exocytosis and/or dispersal of the liberated granule content. Presently it is known that various morphological changes, such as cellular swelling, potassium leakage and hydration of the endoplasmic reticulum and of the mitochondria, do occur in somatic cells exposed to endotoxin (Silver, 1981).

The rate of parthenogenetic activation in ova co-cultured with BOEC was comparable to that reported by Brackett et al (1989) and Süss et al (1990) after culture with and without cellular support.

Fishel et al (1988) noted a significantly greater degree of cytoplasmic fragments in human embryos exposed to culture medium contaminated with endotoxin at a level $>1 \mathrm{ng} / \mathrm{ml}$. By contrast, fragmentation did not occur in the bovine embryos in the present study.

The high proportion of ova that developed to the blastocyst stage by $\mathrm{d} 8$ indicated suitability of the culture condition, with and without endotoxin during sperm prep- aration and co-culture of gametes. Additionally, it must be noted that embryo development occured in spite of the unexpected and moderate $(<1 \mathrm{ng} / \mathrm{ml})$ concentration of endotoxin in the embryo culture medium (table 1 ). The proportion of $d 8$ blastocysts that had hatched by $d 10$ was greater for those of the non-contaminated group, but not significantly different from the endotoxin-contaminated group. We selected hatching as the final stage at which to study the effect of endotoxin, as we believe it is the most appropriate endpoint for in vitro assessment of the viability of embryos derived by in vitro techniques. ChenLu and Lu (1990), who also used hatching as an endpoint for analysis, reported that $69 \%$ of the blastocysts in their study hatched. This rate is similar to that for our group of blastocysts not exposed to endotoxin.

It is not known whether exposure of bovine gametes to endotoxin has a detrimental effect on pregnancy. However in the human, the presence of endotoxin during in vitro fertilization results in a very reduced occurrence of pregnancy (Snyman and Van der Merwe, 1986), particularly when the endotoxin level is $>1 \mathrm{ng} / \mathrm{ml}$ (Fishel et al, 1988).

In conclusion, our data indicated that the presence of endotoxin during sperm preparation and sperm oocyte co-culture results in an increased rate of polyspermy. Otherwise, no adverse effects of endotoxin were noted.

\section{REFERENCES}

Box GEP, Hunter WG, Hunter JS, (1978) Statistics for Experimenters. John Wiley and Sons Inc, NY $653 \mathrm{pp}$

Brackett BG, Younis Al, Fayrer-Hosken RA (1989) Enhanced viability after in vitro fertilization of bovine oocytes matured in vitro with high concentrations of luteinizing hormone. Fertil Steril 52, 319-324 
Chen-Lu HB, Lu KH (1990) Effect of protein supplements on in vitro maturation, fertilization and culture to blastocyst and hatching stage of bovine oocytes. Theriogenology 33, 205

Culbertson Jr R, Osburn BI (1980) The biologic effects of bacterial endotoxin: a short review. Vet Sci Commun 4, 3-14

First NL, Parrish JJ (1987) In vitro fertilization of ruminants. J Reprod Fertil (suppl) 34, 151 . 165

Fishel S, Jackson P, Webster J, Faratian B (1988) Endotoxins in culture medium for human in vitro fertilization. Fertil Steril 49, 108 111

Freer JH, Arbuthnott JP (1976) Biochemical and morphologic alterations of membranes by bacterial toxins, In: Mechanisms in Bacterial Toxicology (Bernheimer AW, ed) John Wiley and Sons, Inc, NY, 169-193

Hyttel P, Callesen H, Greve T (1989) A comparative ultrastructural study of in vivo versus in vitro fertilization of bovine oocytes. Anat Embryol 179, 435-442

Lui CW, Cornett LE, Meizel S (1977) Identification of the bovine follicular fluid protein involved in the in vitro induction of the hamster sperm acrosome reaction. Biol Reprod 17 , 34-41

Nowotny A (1971) Relationship of structure and biological activity of bacterial endotoxins. $\mathrm{Na}$ turwissenschaften 58, 397-409

Ménézo $Y$ (1976) Milieu synthétique pour la survie et la maturation des gamétes et pour la culture de l'œuf fécondé. CR Acad Sci Paris Ser D 282, 1967-1970
Parrish JJ, Susko-Parrish JL, Leibfried-Rutledge ML, Critser ES, Eyestone WH, First NL (1986) Bovine in vitro fertilization with frozenthawed semen. Theriogenology 25, 591-600

Raetz CRH, Brozek KA, Clementz T, Coleman JD, Galloway SM, Golenbock DT, Hampton RY (1988) Gram-negative endotoxin: a biologically active lipid. Cold Spring Harbor Symp Quant Biol, 53, 973-982

Silver IA (1981) Some effects of Escherichia coli endotoxin on cells in culture. In: Progress in Clinical and Biological Research (Majde JA, Person RJ, eds) vol 62, Alan R Liss Inc, NY, 81-95

Snyman E, Van Der Merwe JV (1986) Endotoxin-polluted medium in a human in vitro fertilization program. Fertil Steril 46, 273-276

Süss U, Wüthrich K, Stranzinger G (1988) Chromosome configurations and time sequence of the first meiotic division in bovine oocytes matured in vitro. Biol Reprod 38, 871-880

Süss U, Kassner J, Wüthrich K, Stranzinger G (1990) Cumulus expansion, in vitrofertilization and embryonic development after in vitro maturation of bovine oocytes in the presence of follicle stimulating or luteinizing hormone. Reprod Dom Anim 25, 3-13

Viuff D, Madison V, Hyttel P, Avery B, Greve T (1990) Fluorescent intravital staining of bovine oocytes and zygotes. Assisted Reprod Technol / Androl 1, 181-189

Xu KP, Greve T (1988) A detailed analysis of early events during in vitro fertilization of bovine follicular oocytes. J Reprod Fertil 82, 127-134 